\title{
High-resolution imaging of pelagic bacteria by Atomic Force Microscopy and implications for carbon cycling
}

\author{
Francesca Malfatti, Ty J Samo and Farooq Azam \\ Marine Biology Research Division, Scripps Institution of Oceanography, University of California San Diego, \\ La Jolla, CA, USA
}

\begin{abstract}
In microbial oceanography, cell size, volume and carbon (C) content of pelagic bacteria and archaea ('bacteria') are critical parameters in addressing the in situ physiology and functions of bacteria, and their role in the food web and $\mathrm{C}$ cycle. However, because of the diminutive size of most pelagic bacteria and errors caused by sample fixation and processing, an accurate measurement of the size and volume has been challenging. We used atomic force microscopy (AFM) to obtain highresolution images of pelagic bacteria and Synechococcus. We measured the length, width and height of live and formalin-fixed pelagic bacteria, and computed individual cell volumes. AFM-based measurements were compared with those by epifluorescence microscopy (EFM) using 4',6diamidino-2-phenylindole (DAPI). The ability to measure cell height by AFM provides methodological advantage and ecophysiological insight. For the samples examined, EFM (DAPI)-based average cell volume was in good agreement (1.1-fold) with live sample AFM. However, the agreement may be a fortuitous balance between cell shrinkage due to fixation/drying (threefold) and Z-overestimation (as EFM does not account for cell flattening caused by sample processing and assumes that height $=$ width). The two methods showed major differences in cell volume and cell $C$ frequency distributions. This study refines the methodology for quantifying bacteria-mediated C fluxes and the role of bacteria in marine ecosystems, and suggests the potential of AFM for individual cell physiological interrogations in natural marine assemblages.
\end{abstract}

The ISME Journal (2010) 4, 427-439; doi:10.1038/ismej.2009.116; published online 26 November 2009

Subject Category: microbial ecology and functional diversity of natural habitats

Keywords: biovolume; heterotrophic marine bacteria; cyanobacteria; bacteriophage; AFM

\section{Introduction}

Marine bacteria have important functions in oceanic biogeochemical cycles (Pomeroy et al., 2007). Through their actions, they control the fate of the fixed carbon (C) in the ecosystem (Azam et al., 1994). Their role in $C$ cycling is variable, and the strength of coupling between primary $\mathrm{C}$ production and bacterial $\mathrm{C}$ demand is a critical factor in dictating the net trophic state of the system (Azam and Malfatti, 2007). This knowledge has been derived over the past three decades, as methods were developed for measuring bacterial abundance (by epifluorescence microscopy, EFM (Hobbie et al., 1977)), C content, C production and respiration (Fuhrman and Azam, 1980, 1982; del Giorgio and Williams, 2005). The visualization of marine bacteria,

Correspondence: F Malfatti, Marine Biology Research Division, Scripps Institution of Oceanography UCSD, University of California San Diego, 8570 Biological Grade, La Jolla, CA 92093, USA. E-mail: fmalfatti@ucsd.edu

Received 29 May 2009; revised 11 September 2009; accepted 11 September 2009; published online 26 November 2009 which are dominated by diminutive cells, can be considered to be a capstone event in marine microbial ecology (Hobbie et al., 1977). Although electron microscopy (Sieburth, 1975; Johnson and Sieburth, 1982) has also been used to study marine bacteria, EFM has made the capability to count marine bacteria broadly accessible to the scientific community. After the discovery of large populations of bacteria (and later archaea), the next challenge had been to size the cells and compute the biovolume and $\mathrm{C}$ content to quantify the flux of $\mathrm{C}$ through the microbial compartment. Since the late 1970s, many studies have sought to address this challenge to measure the volume of marine bacteria (for a review see Fuhrman, 1981; Sieracki et al., 1985; Suzuki et al., 1993).

The two main steps in sample preparation, fixation and staining, can create significant errors in size determination because of cell distortion and/ or volume change. Fixatives such as formaldehyde cross-link proteins and nucleic acids (Gustavson, 1956; Nie et al., 2007) and cause cell shrinkage. Different dyes have different quantum yields (Cosa et al., 2001). Furthermore, the choice of the cell 
component as a staining target can have a major effect on size measurement by EFM. For instance, DNA staining might not be an optimal choice, as the nucleoid represents a variable fraction of cell volume, as shown in transmission electron microscope (TEM) micrographs of pelagic marine bacteria (Johnson and Sieburth, 1982). Previous EFM studies (Suzuki et al., 1993; Posch et al., 2001; Straza et al., 2009) have shown that sizing with DNA stains underestimates cell volume (for a review see Boelter et al., 2002). Another potentially significant limitation of EFM for cell volume determination is that cell height is typically not accessible. Finally, EFM resolution is limited for reliably examining bacterial interactions with organic matter and with other organisms. Thus, there is need to further develop imaging modalities to measure bacteria in situ cell size, shape and interactions with organisms and organic matter. This should also help to explore the microscale ecophysiology of pelagic bacteria, as well as their role in $\mathrm{C}$ cycling. In view of the fact that a huge amount of data on pelagic bacteria have been gained by $\left(4^{\prime}, 6\right.$-diamidino-2-phenylindole (DAPI)based) EFM, it would be valuable to compare any new approach with this method.

Several high-resolution imaging instruments are available for studying in situ cell size, shape and interactions. Ideally, one would want to be able to examine live bacteria in seawater samples that are maintained in environmental chambers. Although this goal is still challenging, valuable insights can be gained with the application of laser scanning confocal microscopy, deconvolution microscopy and atomic force microscopy (AFM (Binning and Quate, 1986)). These are versatile tools that allow 3D high-resolution imaging in vivo, in natural liquid environmental conditions (Dufrene, 2002, 2008). AFM has been used in microbial oceanography by Kogure's group (Nishino et al., 2004; Seo et al., 2007). Nishino et al. studied the size of marine bacteria in natural assemblages and in cultures. AFM was also used by Seo et al. to investigate the ability of marine bacteria to capture nanoparticles as nutrients. Malfatti and Azam (2009) used AFM to image pelagic bacteria and Synechococcus cells and their microscale associations. They discovered that often a substantial fraction of bacteria and Synechococcus cells in seawater samples were intimately associated with other bacteria. Although this finding has important implications for $\mathrm{C}$ cycling and bacterial ecology, it is also relevant to the required resolution and methodology for counting and sizing bacteria. The application of AFM in microbial oceanography is still in its infancy; however, it is a powerful and versatile tool not only for cell sizing but also for exploring the nanometer to the microscale ecology of marine bacteria.

In this study, we used AFM to study marine bacteria from diverse pelagic marine environments. We investigated the shapes, surface morphology and size distribution of marine bacteria, including
Synechococcus. We imaged live and formalin-fixed samples to address how cell size, shape and biovolume estimates are influenced by sample treatment. Furthermore, we compared volume estimates by AFM and EFM (using DAPI; and we also used three other fluorophores that target DNA, protein or lipid).

\section{Materials and methods}

Sampling and processing for EFM

Seawater samples collected at different locations (Table 1) were fixed with a $0.2-\mu \mathrm{m}$ filtered formaldehyde solution ( $2 \%$ final concentration) and kept at $4{ }^{\circ} \mathrm{C}$ until further processing. Within $24 \mathrm{~h}$, a sample aliquot was filtered either on a $0.2 \mu \mathrm{m}$ Isopore polycarbonate filter (Millipore Corp., Billerica, MA, USA) or a $0.2 \mu \mathrm{m}$ aluminum oxide Anodisc filter (Whatman, Maidstone, UK). Filters were rinsed with $0.02 \mu \mathrm{m}$ filtered Milli-Q water (Millipore Corp.) and let dry, face-up, on a tissue paper in a Petri dish. Filters were then stored at $-20{ }^{\circ} \mathrm{C}$ until further analysis. Bacterial culture details are given in Supplementary information.

\section{Epifluorescence microscopy}

Staining protocol. We compared different stains targeting specific cell components: nucleic acid stains DAPI (H-1200, Vector laboratories Inc., Burlingame, CA, USA) and SYBRGold (S-11494, Invitrogen Corp., Carlsbad, CA, USA); protein stain NanoOrange (N-6666, Invitrogen Corp.); and lipid stain NAO (10-N-nonyl acridine orange; 74395, Sigma-Aldrich, St Louis, MO, USA). The stained samples were viewed at $\times 1000$ on an Olympus BX51 microscope (Olympus, Center Valley, PA, USA). Staining protocol details are given in Supplementary information.

Image processing. The cell volume measurement by EFM is highly sensitive to the method of marking the cell boundary, hence the results are method dependent. Pictures were taken and bacteria were sized with the freeware software Image J (http://rsbweb.nih.gov/ij/). The software was calibrated with a picture of the stage micrometer at $\times 1000$ magnification. In all, 50 to 100 cells were measured per sample. We measure cell dimensions after applying to each image a threshold function and a sharpen filter to identify the edge of the cell. Cell volumes were measured as described by Lee and Fuhrman (1987) and by Posch et al. (1997).

\section{AFM sample preparation}

Dry AFM. The seawater sample was fixed and filtered as for EFM. The filter sample for imaging in air was treated as described in the section above. With sterile scissors, a piece of filter was cut and attached to a glass slide with double-sided sticky 
Table 1 Sampling sites and characteristics

\begin{tabular}{|c|c|c|c|c|c|c|}
\hline Site & Station & Coordinate & Depth (m) & Period & Chl a $\left(\mu g l^{-1}\right)$ & Temperature $\left({ }^{\circ} \mathrm{C}\right)$ \\
\hline \multirow{12}{*}{ Coastal } & \multirow{12}{*}{ SIO } & & \multirow{12}{*}{1} & 1 March 2007 & 5.8 & 14.1 \\
\hline & & & & 10 March 2007 & 3.9 & 14 \\
\hline & & & & 14 March 2007 & 3.1 & 15 \\
\hline & & & & 27 March 2007 & 3.2 & 16 \\
\hline & & & & 29 March 2007 & 3.5 & 15 \\
\hline & & $32.867 \mathrm{~N}$ & & 13 June 2007 & 7.6 & 19.7 \\
\hline & & $117.257 \mathrm{~W}$ & & 11 July 2008 & 2.14 & 19.7 \\
\hline & & & & 27 August 2008 & 9.23 & 23.8 \\
\hline & & & & 31 March 2009 & 3.3 & 14.6 \\
\hline & & & & 20 August 2009 & 0.6 & 22.5 \\
\hline & & & & 21 August 2009 & 0.59 & 22.2 \\
\hline & & & & 23 August 2009 & 0.57 & 21.2 \\
\hline \multirow{7}{*}{ CCE } & \multirow{3}{*}{164} & $35.358 \mathrm{~N}$ & 7 & \multirow{2}{*}{7 April 2007} & 1.2 & 12.5 \\
\hline & & $121.075 \mathrm{~W}$ & 40 & & 1.7 & 11.5 \\
\hline & & & 15 & \multirow{5}{*}{9 April 2007} & 0.18 & 14.4 \\
\hline & \multirow{4}{*}{206} & & 35 & & 0.24 & 14.1 \\
\hline & & $33.659 \mathrm{~N}$ & 100 & & 0.11 & 12.3 \\
\hline & & $123.133 \mathrm{~W}$ & 150 & & - & 9.8 \\
\hline & & & 200 & & - & 9.4 \\
\hline \multirow{9}{*}{ Antarctica } & \multirow{3}{*}{177} & $59.383 \mathrm{~S}$ & 10 & \multirow{3}{*}{21 July 2006} & 0.11 & -0.7 \\
\hline & & $\begin{array}{l}59.383 \mathrm{~S} \\
53.377 \mathrm{~W}\end{array}$ & 50 & & 0.12 & -0.73 \\
\hline & & & 300 & & 0.01 & 1.66 \\
\hline & \multirow{3}{*}{197} & $59.249 \mathrm{~S}$ & 35 & \multirow{3}{*}{25 July 2006} & 0.16 & -0.95 \\
\hline & & $\begin{array}{l}59.249 \mathrm{~s} \\
57.625 \mathrm{~W}\end{array}$ & 75 & & 0.08 & -1 \\
\hline & & & 400 & & 0.01 & 2.05 \\
\hline & \multirow{3}{*}{211} & $62.216 \mathrm{~S}$ & 10 & \multirow{3}{*}{31 July 2006} & 0.04 & -1.27 \\
\hline & & $52.2165 \mathrm{~W}$ & 75 & & 0.02 & -1.32 \\
\hline & & $59.785 \mathrm{~W}$ & 200 & & 0.04 & -1.43 \\
\hline
\end{tabular}

Abbreviation: Chl a, chlorophyll a.

CCE refers to offshore stations in the Southern California Current System, Pacific Ocean.

tape (Veeco Instruments, Santa Barbara, CA, USA). For selected samples, $50 \mu \mathrm{l}$ of fixed seawater was spotted on freshly cleaved mica, allowed to dry completely and rinsed.

Liquid AFM. Seawater was collected and 7-9 ml aliquots were immediately subjected to filtration onto a $0.2 \mu \mathrm{m}$ Anodisc filter (Whatman) while ensuring that the filter never went dry and that a visible layer of liquid was maintained on the filter. The plastic hydrophobic ring designed by the supplier for ease of handling of the filter helps maintain a layer of water on the filter. The wet filter was then attached by velap (vaseline, lanolin, paraffin; Higgins et al., 2002) to a $22 \mathrm{~mm}$ diameter glass slide that was mounted in an environmental chamber.

AFM imaging. Atomic force microscopy imaging was performed with MFP-3D BIO (Asylum Research, Santa Barbara, CA, USA). The AFM is mounted on an inverted epifluorescence microscope (Olympus IX 51, Olympus, Tokyo, Japan). Images were acquired in AC mode. The scan rates were $0.64-1 \mathrm{~Hz}$. The image resolution was $256 \times 256$ or $512 \times 512$. In air, we used silicon nitride cantilever (AC160TS; Olympus) with a spring constant of $42 \mathrm{~N} \mathrm{~m}^{-1}$. In liquid, we used an Au/Cr-coated silicon nitride cantilever (TR400PB; Olympus) with a spring constant of $0.02 \mathrm{Nm}^{-1}$. The AFM image analysis methodology is included in Supplementary information. As the AFM is mounted on an EFM, we used EFM to first identify Synechococcus cells on the basis of their autofluorescence (for details see Supplementary information) and subsequently imaged them by AFM.

Biovolume estimation. We estimated cell biovolume by the formula $V=(\pi / 4) W^{2} \times(L-W / 3)$ (where $L$ is the length and $W$ is the width) (Bratbak, 1985). The assumption is that bacterial shape is either similar to a cylinder with two hemispheres at its ends, where $W=Z$ (cell height), or similar to a sphere where $W=Z=L$.

Owing to cell flattening in fixed and dried samples, another formula can be applied to calculate biovolume, in which the cell shape is thought to approximate a 3D ellipse: $V=4 / 3 \pi \times \mathrm{a} \times \mathrm{b} \times \mathrm{c}$ (with $\mathrm{a}, \mathrm{b}$ and $\mathrm{c}$ being the semi-axes of the solid). This formula has recently been proposed in an AFM study on marine bacteria (Nishino et al., 2004). It requires measuring $W, L$ and $Z$.

\section{Results}

Using AFM, we imaged $>1000$ individual bacteria and 27 Synechococcus cells off Scripps Pier (coastal), 700 bacteria from offshore locations in the Southern 
California Current System and 900 bacteria from the Southern Polar Ocean (Antarctica) in Austral winter (Table 1). (Additional AFM images are presented in Malfatti and Azam, 2009.) We also imaged bacterial isolates BBFL7 (Cytophaga-Flavobacteria; genome sequenced; accession number: AAPD00000000) and SWAT3 (Vibrionacea; genome sequenced; accession number: AAZW00000000). See http://ncbi.nlm.nih. gov for sequences.

\section{Bacteria shape and size}

In AFM images, heterotrophic bacteria were predominantly rods, cocci, c-shaped and s-shaped (Figures 1a and b). We cannot rule out the possibility that other morphologies were present but could not be definitively distinguished from gels and colloids, present abundantly in seawater. Synechococcus cells were either cocci or rods (Figures 1c and d). The bacterial isolates BBFL7 and SWAT3 were rod shaped. The size of natural bacterial assemblages ranged from $<0.2 \mu \mathrm{m}$ to $2 \mu \mathrm{m}$, therefore very small and very large bacteria co-occurred in the same sample.

\section{Cell volume comparison by AFM and EFM}

As standard EFM protocol requires fixed, filtered and dried samples, we performed AFM imaging on parallel samples treated similarly to assess the effect of the technique. EFM samples were stained with DAPI, as it is the most commonly used fluorophore for counting and sizing pelagic bacteria (hence, a large body of contextual data on DAPI-based cell volumes exist from around the World Ocean). We calculated volume as $V=(\pi / 4) W^{2} \times(L-W / 3)$, where $L$ is the length and $W$ is the width (Bratbak, 1985) (see below for volume computation with measured $Z$ by AFM). Assemblage-average cell volume measured by EFM was $0.049 \pm 0.011 \mu \mathrm{m}^{3}$ and by AFM was $0.104 \pm 0.100 \mu \mathrm{m}^{3}$ (Table 2 and Figure 2). We applied a matched pair Wilcoxon sign-rank test (JMP software) to assess whether the observed volume difference by the two methods was statistically significant. The test statistic coefficient was 88 with $P<0.0001$, indicating that the volume estimates by AFM and EFM are statistically different. DAPI-based EFM generally underestimated the assemblage-average cell volume when compared with AFM. On an average, AFM-based volumes were $2 \times \mathrm{EFM}$ on parallel samples; however, this ratio was size-class dependent (see Supplementary Figure 1).

In the case of cultured bacteria, AFM clearly yielded much higher cell volumes than EFM; $V_{\mathrm{AFM}}$ / $V_{\text {EFM }}$ was $\sim 7$ (BBFL7) (data not presented). A likely explanation for the very high $V_{\mathrm{AFM}} / V_{\mathrm{EFM}}$ in cultured bacteria is that, as the cell volume increases, the DAPI-stained nucleoid becomes a smaller fraction of the cell, and it defines the total cell volume poorly.

For Synechococcus cells $(n=27)$, the average volume was $0.39 \pm 0.26 \mu \mathrm{m}^{3}$, with a range of
0.06-1.01 $\mu \mathrm{m}^{3}$ (Table 2). We did not measure Synechococcus cell volume by DAPI.

\section{Stain comparisons}

We compared AFM-based cell volumes with those determined by EFM using four different fluorophores: DAPI and SYBRGold targeting nucleic acids, NanoOrange (NO) targeting proteins and NAO targeting lipids (Table 3). Comparisons of other stains with DAPI were carried out as well. $V_{\text {SYBR }}$ was very high, $4 \times V_{\text {DAPI }}$, and SYBRGold caused intense halos and fluorophore bleeding, hence we did not test it further. $V_{\text {NO }}\left(0.149 \pm 0.116 \mu \mathrm{m}^{3}\right)$ was $2.9 \times V_{\mathrm{DAPI}}$ and showed fair agreement with $V_{\mathrm{AFM}}$ $\left(0.114 \pm 0.102 \mu \mathrm{m}^{3}\right)$. Therefore, using $V_{\mathrm{AFM}}$ as standard, NanoOrange comes close to AFM among the fluorophores tested for EFM-based cell volume quantification. However, the AFM-based volumes were computed on fixed and dried samples (see below for liquid AFM). The lipid stain NAO yielded even lower volumes than $V_{\mathrm{DAPI}}$ and much lower volumes than $V_{\mathrm{AFM}}$ (Table 3 ) (as we used two different filter types, we also evaluated the effect of the membrane on volume determination by EFM; these data are given in Supplementary information).

\section{Cell height by $A F M$}

Atomic force microscopy records probe displacement along the $z$ axis, thus allowing cell height $(Z)$ to be measured. We measured $Z$ for bacteria $\left(Z_{\text {bact }}\right)$ and Synechococcus $\left(Z_{\text {syn }}\right)$ at the coastal site (Table 2). This was first carried out for fixed and dried samples. $Z_{\text {bact }}$ was much lower than cell width $(W)$. The $Z_{\text {bact }}$ average was $55 \pm 24.3 \mathrm{~nm}$, raising the question whether bacteria with a low $Z$ (in the $10-20 \mathrm{~nm}$ class) might be dead (Figure $3 \mathrm{a}$ and Table 2). The $Z_{\text {syn }}$ average was $292 \pm 32 \mathrm{~nm}$, range was $135 \mathrm{~nm}$ to $474 \mathrm{~nm}$, and peaks in height frequency distribution occurred at 201-300 and 301-400 nm (Figure 3b, Table 2). Hence, Synechococcus cells presented a higher $Z$-value than did heterotrophic bacteria (Figures 1c and d). The cultured bacteria, BBFL7 and SAWT3, also presented a variable height range; on an average, the isolates were higher than bacteria in marine assemblages (Figure 3c).

\section{Height in phage-infected bacteria}

We ran two experiments $(n=35$ for BBFL7 and $n=20$ for SWAT3) with a phage-host system to test for a height difference in phage-infected cells versus uninfected cells. We isolated one phage infecting a Flavobacterium, BBFL7, (F Malfatti, unpublished) and a second phage, SIO2, infecting a Vibrio SWAT3 (A-C Baudoux unpublished) from Scripps Pier. The average $Z$ for uninfected BBFL7 was $96 \pm 32.1 \mathrm{~nm}$, whereas the average $Z$ of phage-infected cells was $85 \pm 20.3 \mathrm{~nm}$. An ANOVA (analysis of variance) did not show any difference in $Z$ between treatments 
a

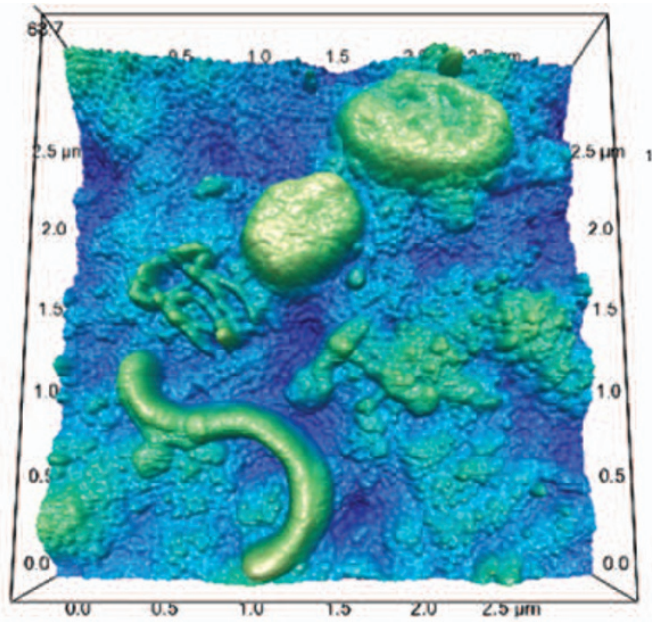

C $366.5 \mathrm{~nm}$

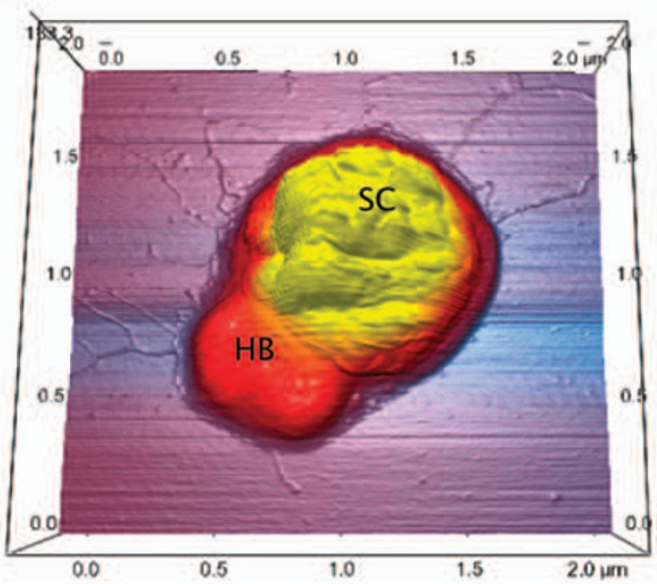

b

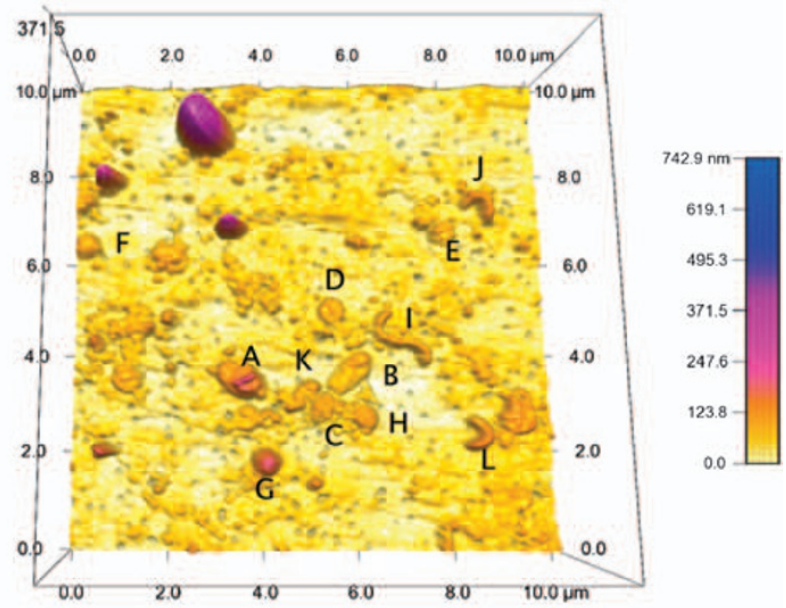

d

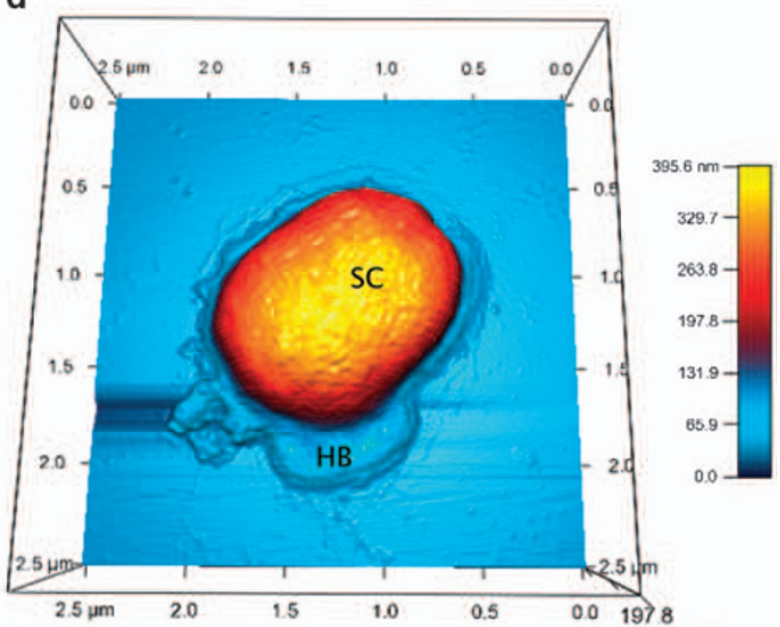

Figure 1 Atomic force microscopy (AFM) topographic images of natural bacterial community and Synechococcus cells. Color bar indicates the Z-range. (a) Sample from a coastal site (10 March 2007) recovered onto a $0.2 \mu \mathrm{m}$-pore-sized Anodisc filter. Two rod-shaped cells and an s-shaped cell are present. The surface of the rod-shaped cells is visibly rougher than that of the s-shaped cell. (b) Sample from an offshore site (station California Current System (CCE) 164 at $7 \mathrm{~m}$ ) filtered onto a $0.2 \mu \mathrm{m}$-pore-sized Isopore filter. Three rodshaped cells (A, B, C), five cocci (D, E, F, G, H), one s-shaped cell (I) and three c-shaped cells (J, K, L) are present. On the top left corner, a high- $Z$ cell is present, possibly a cyanobacterium. (c and d) The Synechococcus cell (SC) associated with a heterotrophic bacterium (HB). The Synechococcus cell was identified by epifluorescence microscopy (EFM) by autofluorescence before AFM scan. The Synechococcus is much larger than the associated heterotrophic bacterium. Samples are (c) from a coastal site and (d) from an offshore site CCE 164 at $7 \mathrm{~m}$.

(F-value $=3.8$ and $P$-value $=0.0553 ;$ JMP software $)$. However, infected cells had a rougher surface than control cells (Figures 4a and b). In the SWAT3-SIO2 system, $Z$ for uninfected SWAT3 was $155 \pm 32.1 \mathrm{~nm}$. In the phage-infected treatment, two different cell morphologies were recognizable and could be attributed to lysed and not lysed cells (Figures 4c and d). The average lysed cell height was $113 \pm 41.2 \mathrm{~nm}$, and cells presented rough surfaces. The average height of phage-exposed but not lysed cells was $244 \pm 45.4 \mathrm{~nm}$. It seems that infected but not lysed cells swell taller before phage release. Alternatively, the higher $Z$ cells were phage resistant and growing actively (hence taller?) at the expense of dissolved organic matter derived from lysed cells. The Tukey-Kramer HSD (honestly significant difference) comparison for all paired tests showed that the $Z$ differences for uninfected cells and lysed and unlysed cells were significantly different (test statistic coefficient was 55.3 with $P<0.0001$; JMP software).

\section{Height-biovolume relationship}

The cell volume calculated by the formula $V=$ $(\pi / 4) W^{2} \times(L-W / 3)$ is overestimated because it is assumed that $Z=W$, which is not true for dried and fixed cells recovered on a filter (as our AFM measurements demonstrated; below). Height reduction of marine bacteria due to sample processing was observed previously by Nishino et al. (2004), but its quantitative significance for estimates of bacterial biomass and $\mathrm{C}$ pools in the ocean has not been made. We propose to use the formula $V=4 / 3 \pi \times a \times b \times c$, where $a, b, c$ are semi-axes of the solid ellipse $(a=$ $L / 2, \mathrm{~b}=W / 2, \mathrm{c}=Z / 2$ ), which considers $Z \neq W$ and uses AFM-based measurements of $Z$ and $W$. 
Table 2 Cell volume and height summary table

\begin{tabular}{|c|c|c|c|c|c|c|c|c|}
\hline \multirow[t]{3}{*}{ Sample ID } & \multirow[t]{3}{*}{ Cell type } & \multirow{3}{*}{$\begin{array}{l}\text { No. of imaged cells } \\
\text { per microscope }\end{array}$} & \multicolumn{4}{|c|}{ Biovolume } & \multirow{2}{*}{\multicolumn{2}{|c|}{$\begin{array}{c}Z \\
A F M(n m)\end{array}$}} \\
\hline & & & \multicolumn{2}{|c|}{$A F M\left(\mu m^{3}\right)$} & \multicolumn{2}{|c|}{$E F M\left(\mu m^{3}\right)$} & & \\
\hline & & & Average & s.d. & Average & s.d. & Average & s.d. \\
\hline 1 March 2007 & HB & 100 & 0.138 & 0.1515 & 0.045 & 0.0258 & 53 & 31.9 \\
\hline 10 March 2007 & $\mathrm{HB}$ & 100 & 0.213 & 0.1809 & 0.040 & 0.0192 & 56 & 26.8 \\
\hline 14 March 2007 & HB & 100 & 0.172 & 0.1363 & 0.043 & 0.0254 & 57 & 47.6 \\
\hline 27 April 2007 & HB & 26 & 0.855 & 0.4100 & 0.083 & 0.0585 & 99 & 19.9 \\
\hline 11 July 2008 & $\mathrm{~S}$ & 14 & 0.329 & 0.2999 & NA & 261 & 71.2 & \\
\hline 27 August 2008 & $\mathrm{~S}$ & 13 & 0.455 & 0.2024 & NA & 323 & 116.5 & \\
\hline 20 August 2009 & HB & 50 & 0.061 & 0.0856 & 0.057 & 0.0293 & 42 & 29.8 \\
\hline 21 August 2009 & HB & 50 & 0.068 & 0.0992 & 0.046 & 0.0241 & 40 & 31.0 \\
\hline 23 August 2009 & HB & 50 & 0.085 & 0.1161 & 0.056 & 0.0333 & 37 & 32.5 \\
\hline $164 \_7$ & HB & 50 & 0.053 & 0.0370 & 0.049 & 0.030 & & \\
\hline 16440 & HB & 50 & 0.080 & 0.1348 & 0.043 & 0.027 & & \\
\hline 206_15 & HB & 50 & 0.054 & 0.0736 & 0.045 & 0.029 & & \\
\hline $206 \_53$ & HB & 50 & 0.033 & 0.0264 & 0.042 & 0.039 & NA & \\
\hline 206_100 & HB & 50 & 0.053 & 0.1572 & 0.040 & 0.031 & & \\
\hline 206_150 & HB & 50 & 0.034 & 0.0790 & 0.035 & 0.022 & & \\
\hline 206_200 & HB & 50 & 0.030 & 0.0579 & 0.040 & 0.030 & & \\
\hline 211_10 & HB & 50 & 0.091 & 0.0730 & 0.055 & 0.078 & NA & \\
\hline $211 \_75$ & HB & 50 & 0.061 & 0.0474 & 0.045 & 0.033 & & \\
\hline 211_200 & HB & 50 & 0.068 & 0.0604 & 0.035 & 0.018 & & \\
\hline 197_35 & HB & 50 & 0.067 & 0.1010 & 0.054 & 0.050 & & \\
\hline $197-75$ & HB & 50 & 0.071 & 0.0847 & 0.050 & 0.036 & & \\
\hline $197 \_400$ & HB & 50 & 0.072 & 0.0659 & 0.054 & 0.055 & & \\
\hline 177_10 & HB & 50 & 0.061 & 0.0947 & 0.068 & 0.070 & & \\
\hline 177_50 & HB & 50 & 0.063 & 0.0772 & 0.066 & 0.066 & & \\
\hline 177_300 & HB & 50 & 0.073 & 0.0919 & 0.041 & 0.027 & & \\
\hline
\end{tabular}

Abbreviations: AFM, atomic force microscopy; EFM, epifluorescence microscopy; DAPI, 4',6-diamidino-2-phenylindole; HB, heterotrophic bacteria; NA, not available; S, Synechococcus cells at coastal site.

Average cell volume estimated by AFM and EFM (DAPI), calculated with the assumption $\mathrm{W}=\mathrm{Z}$ for all the stations. AFM imaging was performed in air (fixed/dried cells).

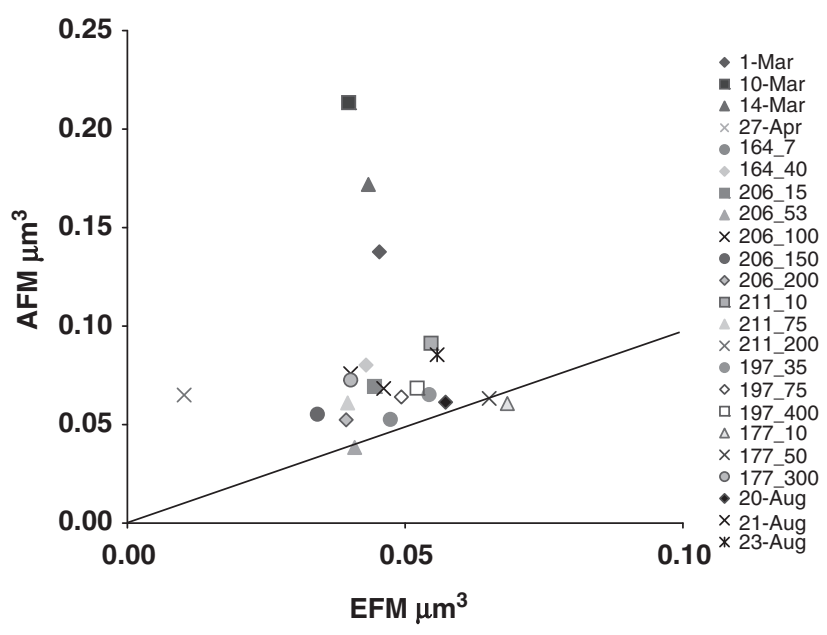

Figure 2 Cell volume by epifluorescence microscopy (EFM) and atomic force microscopy (AFM). Plot shows cell volume of fixed/ dried cells determined on parallel samples and imaged by EFM and AFM. The line is 1:1 line. Volume size-class $<0.01 \mu \mathrm{m}^{3}$ was excluded in calculating the averages. Sample SIO 27-Apr is off-scale $(0.083 ; 0.855)$.

Liquid AFM of natural assemblages and method comparisons

To address the problem of artifacts due to fixation and drying, we compared AFM-based biovolume for live versus formalin-fixed dried marine bacteria assemblages, both of which were concentrated from seawater on $0.2-\mu \mathrm{m}$-pore-sized Anodisc filters (Whatman). Live bacteria $(n=117)$ were imaged in the environmental chamber filled with filtered autoclaved seawater, whereas the formalin-fixed cells $(n=200)$ were imaged in air. The average height of live cells was $164 \pm 140.7 \mathrm{~nm}$, with a range of $15-747 \mathrm{~nm}$ (Figure 5a). The average height of fixed and dried cells was much lower, $52 \pm 35 \mathrm{~nm}$, with a range of 13-197 nm (Figure 5b). The Wilcoxon sign-rank test for matched pairs indicated that the height distributions for live and fixed and dried cells were significantly different (test statistic coefficient was $-3278.5, P<0.0001$; JMP software). The collapse of cell height in fixed/dried cells may have also changed $L$ and $W$. In comparing live versus fixed/dried cells, we observed that $Z$ decreased and $L$ and $W$ increased in fixed/dried samples. In addition, the cell volume in fixed/filtered cells was not conserved, as it can be seen from the calculations given below.

Computing cell volume by assuming $Z=W$, the average volume of live cells is $0.186 \pm 0.420 \mu \mathrm{m}^{3}$ and that for fixed/dried cells is $0.242 \pm 0.39 \mu \mathrm{m}^{3}$. Using the actual measured $Z$ for each cell, the average biovolume of live cells is $0.061 \pm 0.135 \mu \mathrm{m}^{3}$ and for 
Table 3 Cell volume by different stains and by AFM

\begin{tabular}{lcccccc}
\hline \multirow{2}{*}{ Stain } & \multirow{2}{*}{$\begin{array}{c}\text { No. of imaged } \\
\text { cells per } \\
\text { microscope }\end{array}$} & \multicolumn{4}{c}{ Biovolume } \\
\cline { 3 - 4 } & & & \multicolumn{2}{c}{$A F M\left(\mu \mathrm{m}^{3}\right)$} & & \multicolumn{2}{c}{$E F M\left(\mu \mathrm{m}^{3}\right)$} \\
\cline { 3 - 4 } \cline { 6 - 7 } & & Average & s.d. & & Average & s.d. \\
\cline { 3 - 6 } & 50 & $\mathrm{NA}$ & 0.062 & 0.033 & \\
DAPI & 50 & & 0.247 & & 0.269 & \\
SYBRGold & 50 & 0.114 & 0.102 & & 0.149 & 0.116 \\
NanoOrange & 50 & & & 0.051 & 0.039 \\
DAPI & 50 & 0.069 & 0.056 & 0.034 & 0.026 \\
NAO & 50 & & & 0.046 & 0.024 \\
DAPI & & & & &
\end{tabular}

Abbreviations: AFM, atomic force microscopy; EFM, epifluorescence microscopy; DAPI, 4',6-diamidino-2-phenylindole; NA, not available; NAO, 10- $N$-nonyl acridine orange.

Average cell volume determined by AFM and EFM, using different fluorophores. Volume assumption is $\mathrm{W}=\mathrm{Z}$. AFM imaging was performed in air on fixed/dried cells.

fixed/dried cells is $0.021 \pm 0.034 \mu \mathrm{m}^{3}$. Thus, assumption of $Z=W$ overestimates the volume by threefold for live and by 11.5 -fold for fixed/dried cells. The volume frequency distributions were also different (Figure 6). This was seen for live and fixed/dried cells by AFM and by DAPI-EFM (Figure 6). We can consider $0.061 \pm 0.135 \mu^{3}$, the live cell volume based on $Z, W$ and $L$ measurements, as the standard with which to compare volumes determined by other protocols. The EFM-based biovolume using DAPI was $0.055 \pm 0.034 \mu \mathrm{m}^{3}$, only slightly smaller than the live cell volume. However, this similarity is obtained because EFM measurements assume $Z=W$; the actual $Z$ for fixed/filtered/dried cells being $\ll W$ (above) suggests that the similarity of DAPI-based EFM and live cell AFM is because of compensation of errors. Furthermore, the similarity does not hold for all cell volume classes; the Wilcoxon sign-rank test for matched pairs indicated that volume distributions for live cells using actual $Z(Z \neq W)$ and EFM were significantly different (test statistic coefficient was 1657.50, $P<0.0001$; JMP software).

\section{Discussion}

Atomic Force Microscopy is a powerful and versatile tool that produces high-resolution images in three dimensions. However, imaging natural bacterial populations in liquid is still challenging. At the distance of van der Waals forces, cells not firmly attached to the substrate are displaced by the repulsive forces of the scanning probe, thus they are not imaged. We managed to image 117 cells in liquid by immobilizing them by filtering on Anodisc filters while preventing the filter from drying. Chemical reagents, such as poly-L-lysine and PEI, can be applied to the substrate to improve cell adhesion, and we are in the process of optimizing the chemical coating of the substrate. Furthermore, AFM resolution in XY depends on how thin and sharp the probe is, and this
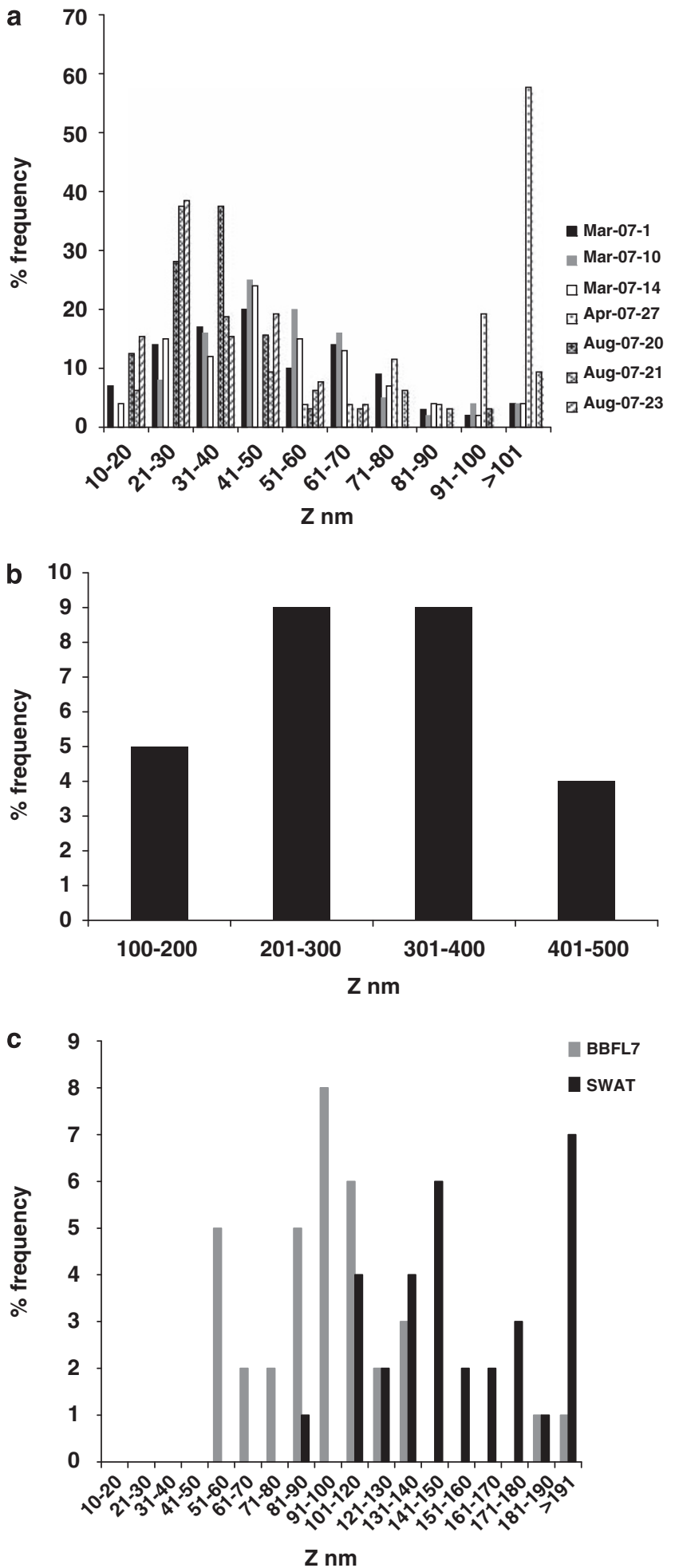

Figure 3 Height frequency distributions. Height, $Z$, was measured by atomic force microscopy (AFM) imaging of fixed/dried cells in air. (a) Heterotrophic bacteria; (b) Synechococcus cells; and (c) BBFL7 and SWAT3.

probe dilation effect tends to cause overestimations in XY measurements (Wong et al., 2007). This point has been discussed for marine bacteria (Nishino et al., 2004), but the degree of overestimation for the natural 
a

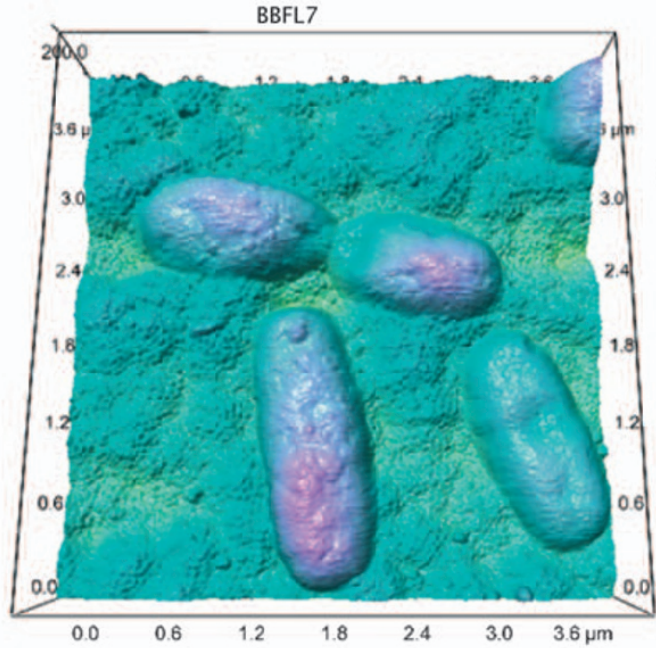

c

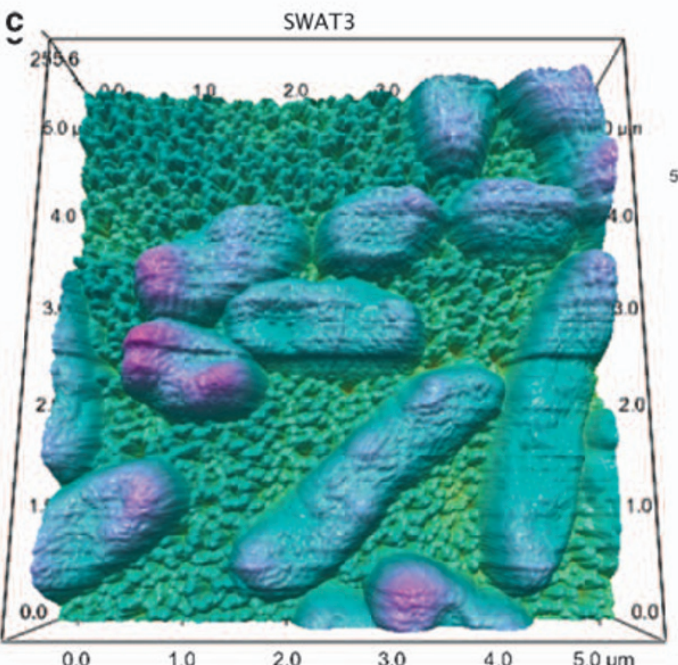

b

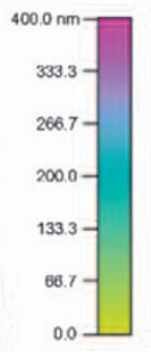

d

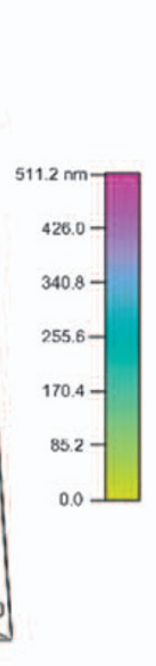

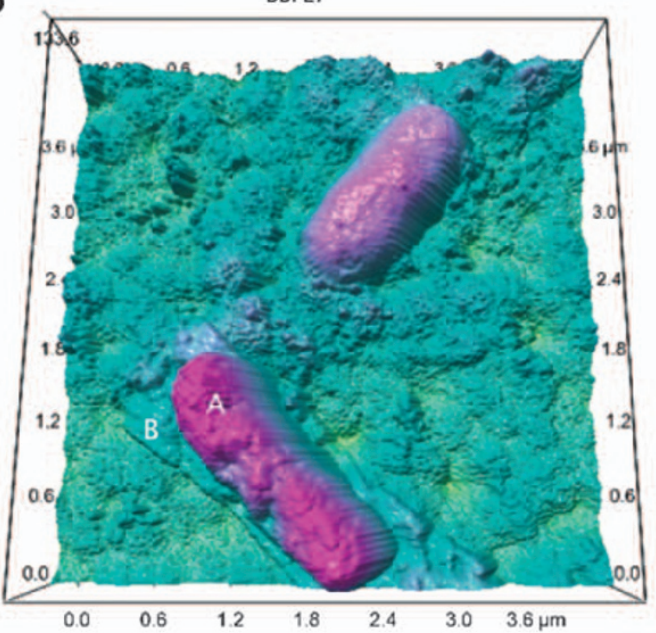

$\left.\begin{array}{c}267.3 \mathrm{~nm} \\ 222.7- \\ 178.2- \\ 133.6- \\ 89.1- \\ 44.5- \\ 0.0\end{array}\right]$

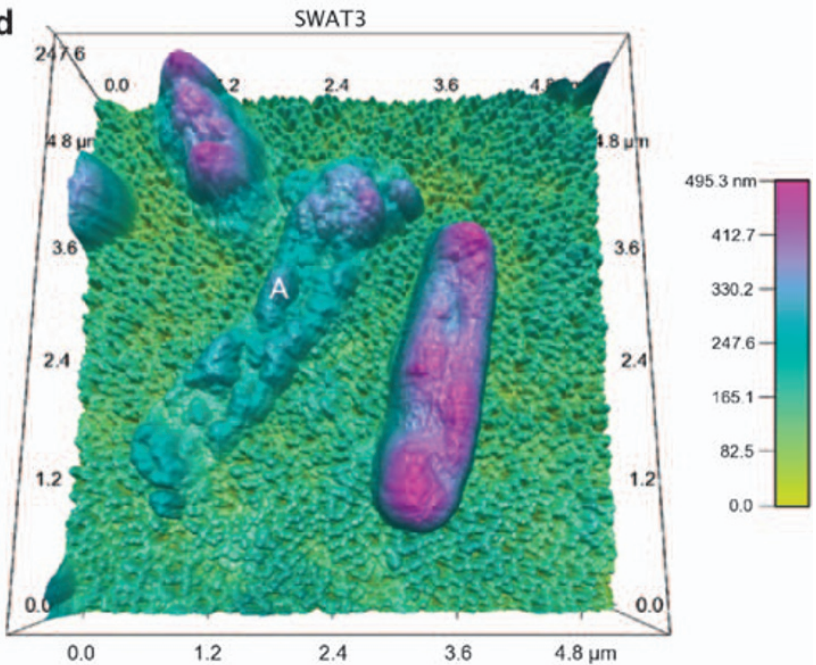

Figure 4 Topographic images of phage-exposed BBFL7 and SWAT3. Cells were collected on a $0.2 \mu$ m Anodisc filter. Color bar indicates the Z-range. (a) BBFL7 control. (b) BBFL7 cells exposed to phage. Note: cell A shows a very rough surface, and cell B is possibly lysed. (c) SWAT3 control. (d) SWAT3 cells exposed to phage SIO2. Note: cell A possibly lysed.

bacterial population is unknown. There is need to intercalibrate (probe specific) AFM measurements of marine bacteria by establishing size standards that are representative in size, shape, surface topography and chemical activity to marine bacteria. Despite these challenges, AFM can begin to provide powerful constraints on hypotheses in microbial biogeochemistry (discussed here and in Malfatti and Azam, 2009).

\section{Bacterial surface and morphology}

Atomic force microscopy has greater (sub-nanometer) resolving power than EFM. The 'small blue dots' in EFM become 'large bacteria' in AFM, with visible surface features interacting with other microbes within the organic matter continuum (Malfatti and Azam, 2009). AFM enables imaging of the bacterial surface, which might provide important information about a cell's physiological state and response to the microniche environment. For instance, in our phage-host systems, the surface of lysed SWAT3 and infected BBFL7 cells was rougher than that of control cells (Figure 4). Such an increase in roughness has also been reported for E. coli 057 and the lytic phage A 157 phage-host system (Dubrovin et al., 2008). Further, AFM studies have shown that mechanical and chemical damage of cell surface results in increased roughness-including damage caused by EDTA (Amro et al., 2000), detergents (Camesano et al., 2000), proteases (F Malfatti, unpublished) (Camesano et al., 2000) and antibiotics (Braga and Ricci, 1998; Meincken et al., 2005). Marine phages lyse $10-50 \%$ of bacteria production in the upper ocean, and it would be interesting to observe if phage-infected bacteria and archaea could be identified through a surface 'signature'.

We imaged >2600 marine bacteria cells but encountered only four general shaped ones: cocci, rods, s-shape and c-shape (Figure 1). Synechococcus 
a
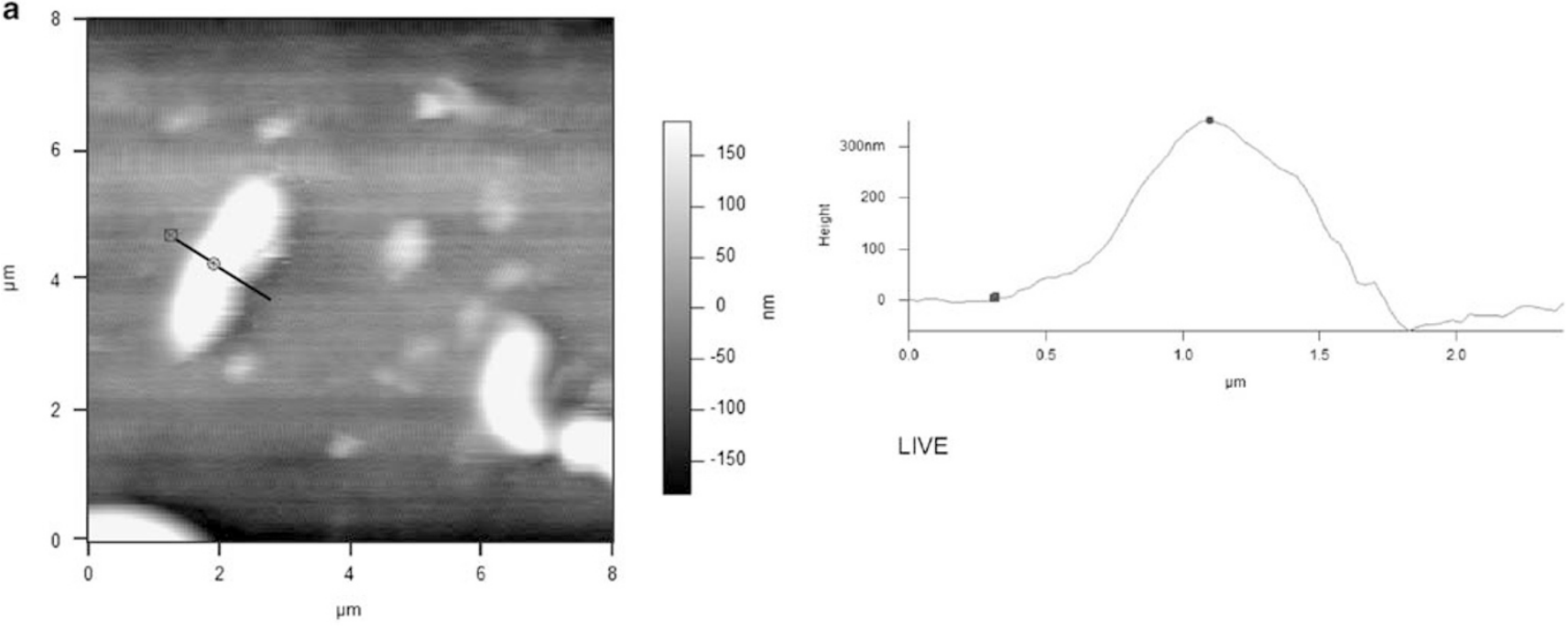

LIVE

b
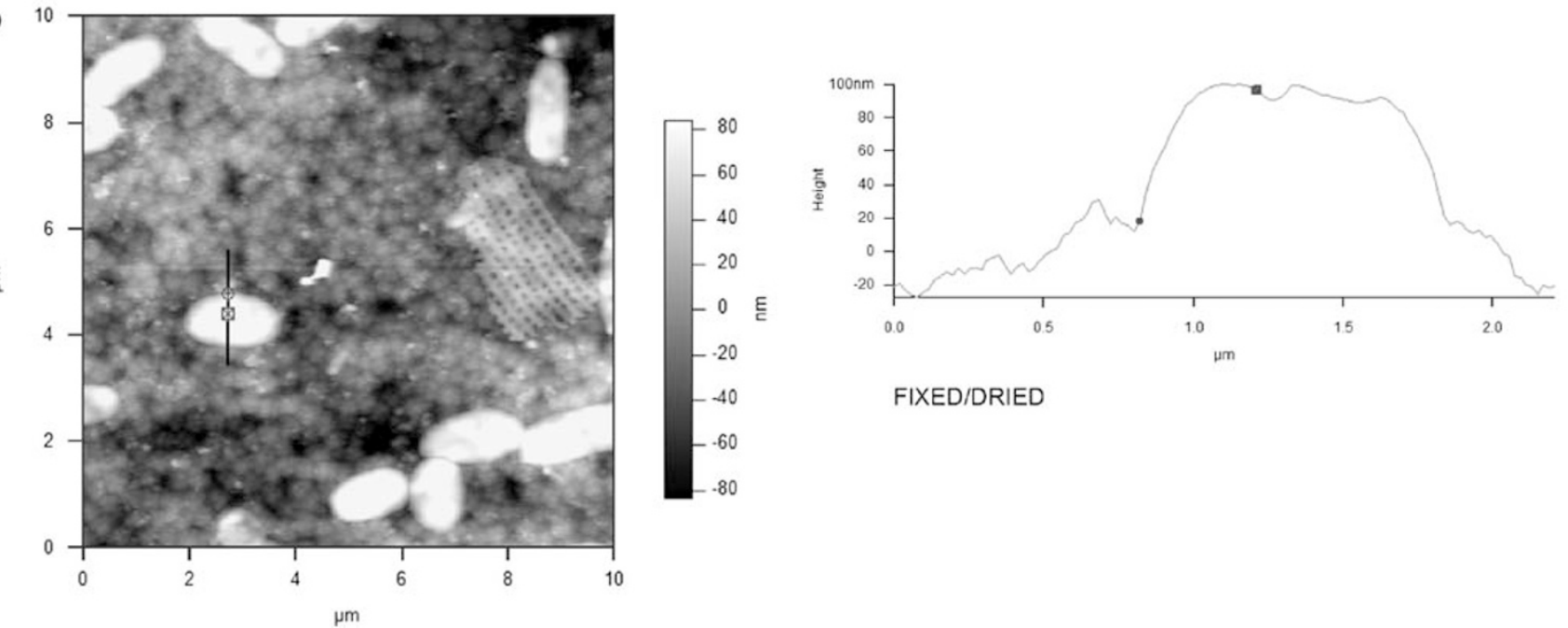

FIXED/DRIED

Figure 5 Live and formalin-fixed/dried heterotrophic bacteria. Atomic force microscopy (AFM) imaging of live (a) and fixed/dried (b) cells (the gray scale bar indicates the $Z$-range and the black thick line is a ruler). Bacteria from the coastal site were imaged on a $0.2 \mu \mathrm{m}$ Anodisc filter. (a) AFM height image of live bacteria acquired in liquid, and relative section graph of cell height. Note: the profile line shows a smooth cell surface; (b) AFM height image of fixed/dried bacteria acquired in air, and relative section graph of cell height. Note: the profile shows a rough cell surface. A full colour version of this figure is available at The ISME Journal online.

cells were also either cocci or rods (Figures 1c and d) (indicating pleiomorphism that might be related to a difference in light regime (Ahlgren and Rocap, 2006; Palenik et al., 2006) and/or grazing pressure (Christaki et al., 1999, 2005)). Previous scanning electron microscope and TEM imaging of marine bacteria (Costerton et al., 1981) (Sieburth, 1975) (Heissenberger et al., 1996), as well as recent AFM studies of marine bacteria (Nishino et al., 2004) (Seo et al., 2007), reported shapes similar to those in this study. As cell shape has adaptive value (Cabeen and Jacobs-Wagner, 2005), one might speculate that, despite their varied biogeochemical functions in ocean ecosystems, bacteria maintain few common shapes that are optimized for survival in the pelagic environment. An alternative hypothesis is that pelagic bacteria have many other shapes but we have not observed them because they co-occur with a great morphological diversity of marine gels and colloids. Concurrent high-resolution EFM $(\times 1000$; currently not feasible in our AFM system) should help to search for bacteria with other shapes, and for their adaptive value (for example, bacteria in marine snow).

\section{Biovolume measurement by AFM}

In addition to EFM, and the recent use of AFM, electronic counters (flow cytometer and Coulter counter (Kubitschek, 1969)) have often been used to estimate bacteria volume. An advantage of electronic counters and flow cytometers is that they interrogate the individual cell in its native morphology-unless the protocol requires chemical fixation. Imaging-based techniques have the advantage of providing information on bacteria and their 


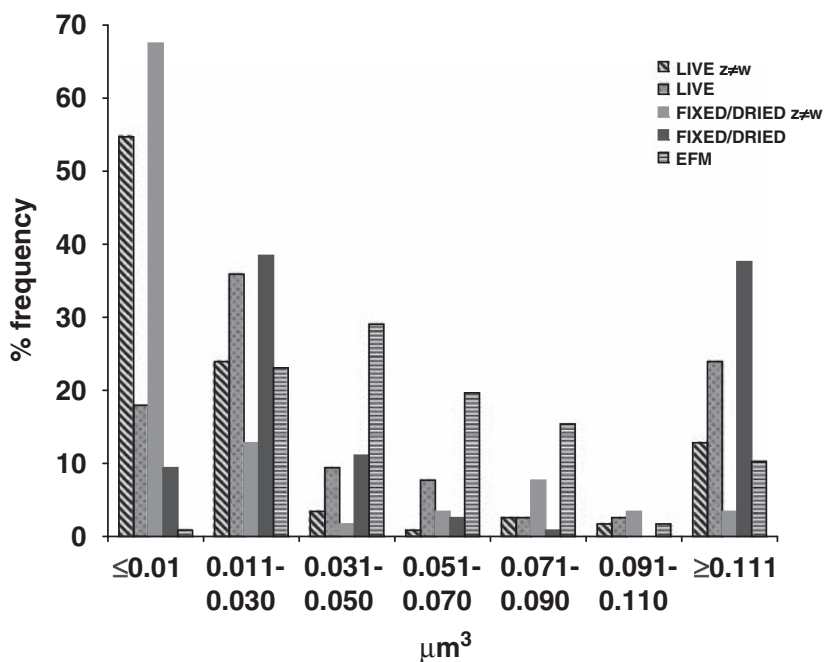

Figure 6 Volume frequency distribution for live and fixed/dried bacteria by atomic force microscopy (AFM) and epifluorescence microscopy (EFM). Cell volumes by AFM were computed assuming both $Z \neq W$ (labeled in sample legend) and $W=Z$ (note labeled in sample legend).

associations with other bacteria or organic matter. A dramatic example is our AFM-based finding (Malfatti and Azam, 2009) that often a substantial but variable fraction (21-43\%) of pelagic heterotrophic bacteria and Synechococcus cells occurred conjoint with other bacteria (in Figures 1c and d, showing Synechococcus cell conjoint with heterotrophic bacterium). Electronic counters might treat conjoint bacteria as a single, larger cell. Distinguishing high and low DNA cells in pelagic bacterial populations (Bouvier et al., 2007; Falcioni et al., 2008) by flow cytometer might also be affected by low DNA conjoint heterotrophic bacteria being treated as a single high DNA cell. Further, AFM can provide a wealth of information on the bacterium's microscale ecology that goes well beyond the initial intent to know the cell volume and $\mathrm{C}$ content.

\section{Biovolume-a matter of height}

In EFM, cell width and length are measured and used to calculate $V=(\pi / 4) W^{2} \times(L-W / 3)$. Two assumptions are made: (1) a bacterial cell can be approximated to a cylinder with hemispheres $(W=Z)$ at its ends, or a sphere $(W=L)$; and (2) a bacterial cell maintains its shape, size and volume on the filter. We have provided a quantitative context to the cautionary note of Nishino et al (2004). Because $Z \neq W$, we compared live imaging as a reference by which we could assume volume conservation. Our results show that EFM-based volumes of marine bacteria are likely to be significantly in error. We found that fixation and drying, standard practice in EFM, has a large contribution to the decrease in $Z$ (Figure 5) and its effect on $V$ if it is calculated without taking the extent of cell flattening into account.

By applying the 3D ellipse approximation to our measurements on live cells, the average volume was determined to be $0.061 \mu \mathrm{m}^{3}$ and this volume was threefold less than if we assumed $W=Z\left(0.186 \mu \mathrm{m}^{3}\right)$. The average volume computed by $\operatorname{EFM}(n=200)$ was 1.1-fold less than the volume of the live cell by AFM $(n=117)$ using 3D ellipse approximation. Thus, at least for the samples we imaged, the average cell volume computed by EFM was 'right for the wrong reason'-apparently the use of $Z=W$ compensated for cell shrinkage due to fixation. Importantly, our results show that the error is likely to be quite variable as it is dependent on the size frequency distribution of the assemblage (see Supplementary Figure 1).

\section{Bacterial height and physiological state}

The large height range by AFM for live cells $(15-747 \mathrm{~nm})$ can be due to volume differences among species and/or within-species volume differences in cells in varied physiological states (possibly because of exposure to varied microniches). Both causes are likely to be operative. It is also interesting to ask whether in the natural assemblage a certain low range of height indicates dying or dead cells.

Zweifel and Hagström (1995) concluded that only a small fraction, only $2-32 \%$, of the total DAPI-EFM count, is comprised of cells that contain nucleoids, the remainder being 'ghosts' presumably including bacteria lysed by phage. Bacteria mortality by viral attack is an important aspect in the marine $\mathrm{C}$ cycle. Phages are responsible for $10-50 \%$ of bacteria mortality in the upper ocean (reviewed by Fuhrman, 1999), and up to $32 \%$ of heterotrophic bacteria and $15 \%$ of Cyanobacteria can be infected (Proctor and Fuhrman, 1990). On the basis of our AFM-based $Z$ measurements of natural bacterial population, phage-lysed and formalin-fixed bacteria (cultured isolates; Figure 4), we suggest that cells $<20-30 \mathrm{~nm}$ $Z$-class might mainly comprise dead bacteria. To determine the height and morphology of virusinfected bacteria, it would be necessary to simultaneously use AFM and TEM (as TEM enables the detection of visibly infected bacteria (Steward et al., 1992; Wommack et al., 1992)). This should be feasible by performing AFM, followed by TEM (the position of the AFM-imaged cell could be marked for subsequent TEM). Furthermore, it would be informative to establish a relationship between individual cell physiology and AFM-based interrogation. This could be approached by developing protocols that combine AFM with indicators of individual cell physiological state and cell viability, such as CTC (5-cyano-2,3-ditolyl tetrazolium chloride) and live/dead stain (Invitrogen Corp.) (see del Giorgio and Gasol (2008) for a review and the debate on validity of the use of these indicators). 
Bacterial biovolume and its implication for the $C$ cycle Cell biovolume and the associated $\mathrm{C}$ distribution are functions of community diversity (Straza et al., 2009), metabolic activity level (Mitchell, 1991), grazing pressure (Simek and Chrzanowski, 1992; Corno and Jurgens, 2006) and phage infection (Dubrovin et al., 2008). As expected, AFM has shown large variations in biovolume classes of natural mixed assemblages. Potentially different cells had different $\mu$ (specific growth rate) and were living in specific microniches. As the $\mathrm{C}$ to volume ratio has been shown to vary with cell volume, the cell volume frequency distribution of the assemblage needs to be considered in computing assemblage cell C (Simon and Azam, 1989). This is also important in comparing AFM-based volume with EFM-based volume. Although we found the average values to be very similar $(\mathrm{AFM}=1.1 \times \mathrm{EFM})$, the volume frequency distributions were markedly different (Figure 6).

Converting cell volume to cell $\mathrm{C}$ content is an important goal in understanding the role of bacteria in the marine $\mathrm{C}$ cycle. However, various studies have reported a different $\mathrm{C}$ to volume ratio, presumably because of a difference in methods (Lee and Fuhrman, 1987; Simon and Azam, 1989; Garrison et al., 2000; Posch et al., 2001; Gundersen et al., 2002). (See Posch et al., 2001 for a detailed discussion on volume-to-C conversion factors.) The direct measurement of cell $\mathrm{C}$ in conjunction with AFM-based biovolume would be ideal for establishing a cell volume cell $\mathrm{C}$ relationship; this was not carried out in this study. Here, we used the power function $y=88.6 x^{0.59}$ to convert volume to cell protein, which is proportional to $\mathrm{C}(\mathrm{C}=$ protein $\times 0.86)$ (Simon and Azam, 1989) for live AFM and EFM samples (Figure 7).

Of the live AFM bacterial population, $80 \%$ had a $\mathrm{C}$ content $<10 \mathrm{fg}$ per cell including $50 \%$ with $<5 \mathrm{fg}$ per cell, whereas $12 \%$ had a very high $\mathrm{C}$ content of $>31 \mathrm{fg}$ per cell. In sharp contrast, EFM showed the virtual absence of cells in the $<5 \mathrm{fg} C$ per cell and $>31 \mathrm{fg} \mathrm{C}$ per cell classes. The high frequency of the $<5 \mathrm{fg} C$ per cell class in live AFM is difficult to explain, and the occurrence of bacteria with such a small $\mathrm{C}$ content merits further study. These $<5 \mathrm{fg} C$ cells comprise only $17 \%$ of the total assemblage C. It is also noteworthy that EFM appears to underestimate the volumes of $>31 \mathrm{fg} \mathrm{C}$ cells. This size-class of cells (12\% of total) was estimated to contain $49.7 \%$ of the total assemblage $\mathrm{C}$ by live AFM and only $2.1 \%$ by EFM.

The large disparity in bacteria $C$ per cell pool assignment by AFM and EFM has important consequences for analysis of bacteria production and $\mathrm{C}$ flow pathways. The AFM-based detection of high $\mathrm{C}$ bacteria has implications for understanding and quantifying size-dependent grazing on bacteria by the protists. Further, bacteria $\mathrm{C}$ production by ${ }^{3} \mathrm{H}-$ thymidine incorporation requires a knowledge of per-cell C (estimates of average values often used are

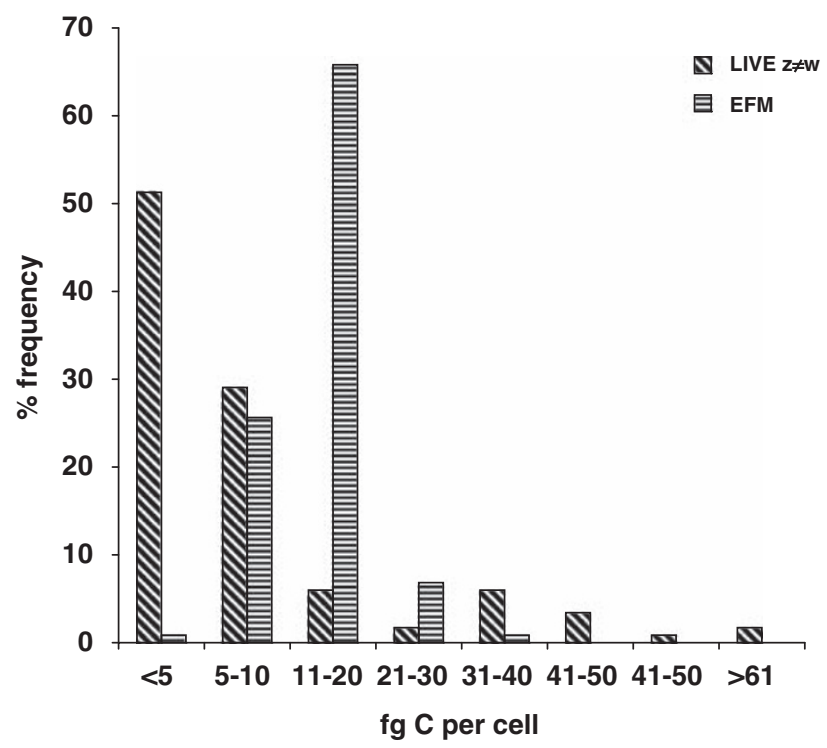

Figure 7 Distribution of carbon content per cell for live and fixed/dried bacteria by atomic force microscopy (AFM) and epifluorescence microscopy (EFM). Live bacteria were measured under environmental conditions by AFM and cell volume was calculated using actual measured $Z$ and assuming $Z \neq W$. Volume of 4',6-diamidino-2-phenylindole (DAPI)-stained cells was measured by EFM, assuming $W=Z$. Carbon content was calculated by the power function $y=88.6 x^{0.59}$, where $\mathrm{x}$ is the cell volume and $\mathrm{y}$ is the protein content (protein $\times 0.86=\mathrm{C}$, see text).

11 fg C per cell (Garrison et al., 2000) or $20 \mathrm{fg} C$ per cell (Simon and Azam, 1989)). AFM-based estimates could result in an upward revision in the contribution of a large cell class in bacteria production and $\mathrm{C}$ flux through the microbial loop.

\section{Conclusion}

This study provides novel information on the biogeochemically significant characteristics of pelagic marine bacteria. The capability to measure cell height with AFM literally adds a new dimension to the current observations by EFM and should help future refinements in bacteria $\mathrm{C}$ content and role in biogeochemical fluxes. AFM should be particularly useful for addressing mechanistic questions on individual cell physiology and interactions at the microscale; this should particularly aid the capability to interrogate live bacteria in seawater.

\section{Acknowledgements}

We thank Maura Manganelli, Jessica Ward and AnneClarie Baudoux for kindly providing samples from BWZ II cruise 2006 in Antarctica, CCE LTER Process Cruise 2007 and from the SWAT3 phage experiment. We thank Krystal Rypien for her help on the statistical test. We thank Katherine Barbeau and Melissa Garren for their comments. We thank Asylum Research folks for AFM support. Chlorophyll and temperature data were retrieved from the SCCOOS data archive (www.sccoos.org) supported by NOAA, from the CCE LTER data archive (http:// oceaninformatics.ucsd.edu/datazoo/data) supported by 
the Division of Ocean Sciences, NSF Grant OCE-0417616 and from the BWZ II website supported by NSF Grant ANT- 0444134 to FA. This work was supported by grants from the Gordon and Betty Moore Foundation Marine Microbiology Initiative and from NSF to FA.

\section{References}

Ahlgren NA, Rocap G. (2006). Culture isolation and culture-independent clone libraries reveal new marine Synechococcus ecotypes with distinctive light and N physiologies. Appl Environ Microbiol 72: 7193-7204.

Amro NA, Kotra LP, Wadu-Mesthrige K, Bulychev A, Mobashery S, Liu GY. (2000). High-resolution atomic force microscopy studies of the escherichia coli outer membrane: structural basis for permeability. Langmuir 16: 2789-2796.

Azam F, Malfatti F. (2007). Microbial structuring of marine ecosystems. Nat Rev Microbiol 5: 782-791.

Azam F, Smith DC, Steward GF, Hagström Å. (1994). Bacteria-organic matter coupling and its significance for oceanic carbon cycling. Microb Ecol 28: 167-179.

Binning G, Quate CF. (1986). Atomic force microscopy. Phys Rev Lett 56: 930-933.

Boelter M, Bloem J, Meiners K, Moller R. (2002). Enumeration and biovolume determination of microbial cells - a methodological review and recommendations for applications in ecological research. Biol Fertil Soils 36: 249-259.

Bouvier T, del Giorgio PA, Gasol JM. (2007). A comparative study of the cytometric characteristics of high and low nucleic-acid bacterioplankton cells from different aquatic ecosystems. Environ Microbiol 9: 2050-2066.

Braga PC, Ricci D. (1998). Atomic force microscopy: application to investigation of Escherichia coli morphology before and after exposure to cefodizime. Antimicrob Agents Chemother 42: 18-22.

Bratbak G. (1985). Bacteria biovolume and biomass estimations. Appl Environ Microbiol 49: 1488-1493.

Cabeen MT, Jacobs-Wagner C. (2005). Bacterial cell shape. Nat Rev Microbiol 3: 601-610.

Camesano AT, Natan MJ, Logan BE. (2000). Observation of changes in bacterial cell morphology using tapping mode atomic force microscopy. Langmuir 16: 4563-4572.

Christaki U, Jacquet S, Dolan JR, Vaulot D, Rassoulzadegan F. (1999). Differential grazing and growth on Prochlorococcus and Synechococcus by two contrasting ciliates. Limnol Oceanogr 44: 52-61.

Christaki U, Vazquez-DomÍnguez E, Courties C, Lebaron P. (2005). Grazing impact of different heterotrophic nanoflagellates on eukaryotic Ostreococcus tauri and prokaryotic picoautotrophs Prochlorococcus and Synechococcus. Environ Microbiol 7: 1200-1210.

Corno G, Jurgens K. (2006). Direct and indirect effects of protist predation on population size structure of a bacterial strain with high phenotypic plasticity. Appl Environ Microbiol 72: 78-86.

Cosa G, Focsaneanu KS, McLean JRN, McNamee JP, Scaiano JC. (2001). Photophysical properties of fluorescent dna-dyes bound to single- and double-stranded dna in aqueous buffered solution. Photochem Photobiol 73: 585-599.
Costerton JW, Irvin RT, Cheng KJ. (1981). The bacterial glycocalyx in nature and disease. Ann Rev Microbiol 35: 299-324.

del Giorgio PA, Gasol JM. (2008). Physiological structure and single-cell activity in marine bacterioplankton. In: Kirchman DL (ed). Microbial Ecology of the Oceans. John Wiley \& Sons Inc.: Hoboken, NJ, pp 243-298.

del Giorgio PA, Williams PJlB (eds). (2005). The global significance of respiration in aquatic ecosystems: From single cells to the biosphere. In: Respiration in Aquatic Ecosystems. Oxford University Press: New York, pp 2667-2673.

Dubrovin EV, Voloshin AG, Kraevsky SV, Ignatyuk TE, Abramchuk SS, Yaminsky IV et al. (2008). Atomic force microscopy investigation of phage infection of bacteria. Langmuir 24: 13068-13074.

Dufrene YF. (2002). Atomic force microscopy, a powerful tool in microbiology. J Bacteriol 184: 5205-5213.

Dufrene YF. (2008). Atomic force microscopy and chemical force microscopy of microbial cells. Nat Protoc 3: 1132-1138.

Falcioni T, Papa S, Gasol JM. (2008). Evaluating the flowcytometry nucleic acid double staining protocol in realistic situations of planktonic bacterial death. Appl Environ Microbiol 74: 1767-1779.

Fuhrman JA. (1981). Influence of method on the apparent size distribution of bacterioplankton cell: epifluorescence microscopy compared to scanning electron microscopy. Mar Ecol Prog Ser 5: 103-106.

Fuhrman JA. (1999). Marine viruses and their biogeochemical and ecological effects. Nature 399: 541-548.

Fuhrman JA, Azam F. (1980). Bacterioplankton secondary production estimates for coastal waters of British Columbia, Antarctica and California. Appl Environ Microbiol 39: 1085-1095.

Fuhrman JA, Azam F. (1982). Thymidine incorporation as a measure of heterotrophic bacterioplankton production in marine surface waters: evaluation and field results. Mar Biol 66: 109-120.

Garrison DL, Gowing MM, Hughes MP, Campbell L, Caron DA, Dennett MR et al. (2000). Microbial food web structure in the Arabian Sea: a US JGOFS study. Deep Sea Res Part 2 Top Stud Oceanogr 47: 1387-1422.

Gundersen K, Heldal M, Norland S, Purdie DA, Knap AH. (2002). Elemental C, N, and P cell content of individual bacteria collected at the Bermuda Atlantic Time-series Study (BATS) site. Limnol Oceanogr 47: 1525-1530.

Gustavson KH. (1956). The Chemistry of Tanning Processes. Academic Press: New York.

Heissenberger A, Leppard G, Herndl G. (1996). Ultrastructure of marine snow. II. Microbiological considerations. Mar Ecol Prog Ser 135: 299-308.

Higgins MJ, Crawford SA, Mulvaney P, Wetherbee R. (2002). Characterization of the adhesive mucilages secreted by live diatom cells using atomic force microscopy. Protist 153: 25-38.

Hobbie JE, Daley RJ, Jasper S. (1977). Use of nuclepore filters for counting bacteria by fluorescence microscopy. Appl Environ Microbiol 33: 1225-1228.

Johnson PW, Sieburth JM. (1982). In-situ morphology and occurrence of eukaryotic phototrophs of bacterial size in the picoplankton of estuarine and oceanic waters. J Phycol 18: 318-327.

Kubitschek HE. (1969). Counting and sizing micro-organisms with the Coulter Counter. Methods Microbiol 1: 593-610. 
Lee S, Fuhrman JA. (1987). Relationships between biovolume and biomass of naturally derived marine bacterioplankton. Appl Environ Microbiol 53: 1298-1303.

Malfatti F, Azam F. (2009). Atomic force microscopy reveals microscale networks and possible symbioses among pelagic marine bacteria. Aquat Microb Ecol (in press).

Meincken M, Holroyd DL, Rautenbach M. (2005). Atomic force microscopy study on the effect of antimicrobial peptides on the cell envelope of Escherichia coli. Antimicrob Agents Chemother 49: 4085-4092.

Mitchell J. (1991). The influence of cell size on marine bacterial motility and energetics. Microb Ecol 22: 227-238.

Nie CL, Yan Wei Y, Chen X, Liu YY, Dui W, Liu Y et al. (2007). Formaldehyde at low concentration induces protein tau into globular amyloid-like aggregates in vitro and in vivo. Plos ONE 2: e629.

Nishino T, Ikemoto E, Kazuhiro K. (2004). Application of atomic force microscopy to observation of marine bacteria. J Oceanogr 60: 219-225.

Palenik B, Ren Q, Dupont CL, Myers GS, Heidelberg JF, Badger JH et al. (2006). Genome sequence of Synechococcus CC9311: Insights into adaptation to a coastal environment. Proc Natl Acad Sci 103: 13555-13559.

Pomeroy LR, Williams PJL, Azam F, Hobbie JE. (2007). The microbial loop. Oceanography 20: 28-33.

Posch T, Loferer-Kroessbacher M, Gao G, Alfreider A, Pernthaler J, Psenner R. (2001). Precision of bacterioplankton biomass determination: a comparison of two fluorescent dyes, and of allometric and linear volume-to-carbon conversion factor. Aquat Microb Ecol 25: 55-63.

Posch T, Pernthaler J, Alfreider A, Psenner R. (1997). Cellspecific respiratory activity of aquatic bacteria studied with the tetrazolium reduction method, cyto-clear slides, and image analysis. Appl Environ Microbiol 63: 867-873.

Proctor LM, Fuhrman JA. (1990). Viral mortality of marine bacteria and cyanobacteria. Nature 343: 60-62.
Seo Y, Eiko I, Akihiro Y, Kazuhiro K. (2007). Particle capture by marine bacteria. Aquat Microb Ecol 49: 243-253.

Sieburth JM. (1975). Microbial Seascape: A Pictorial Essay On Marine Microorganisms And Their Environments. University Park Press: Baltimore.

Sieracki ME, Johnson PW, Seiburth JM. (1985). Detection, enumeration, and sizing of planktonic bacteria by image-analyzed epifluorescence microscopy. Appl Environ Microbiol 49: 799-810.

Simek K, Chrzanowski TH. (1992). Direct and indirect evidence of size-selective grazing on pelagic bacteria by freshwater nanoflagellates. Appl Environ Microbiol 58: $3715-3720$.

Simon M, Azam F. (1989). Protein content and protein synthesis rates of planktonic bacteria. Mar Ecol Prog Ser 51: 201-213.

Steward GF, Wikner J, Smith DC, Cochlan WP, Azam F. (1992). Estimation of virus production in the sea: I. Method development. Mar Microbial Food Webs 6: 57-78.

Straza TRA, Cottrell MT, Ducklow HW, Kirchman DL. (2009). Geographic and phylogenetic variation in bacterial biovolume using protein and nucleic acid staining. Appl Environ Microbiol 75: 4028-4034.

Suzuki MT, Sherr EB, Sherr BF. (1993). DAPI direct counting underestimates bacterial abundances and average cell size compared to AO direct counting. Limnol Oceanogr 38: 1566-1570.

Wommack KE, Hill RT, Kesel M, Russek-Cohen E, Colwell R. (1992). Distribution of viruses in the Chesapeacke Bay. Appl Environ Microbiol 58: 2965-2970.

Wong C, West P, Olson K, Mecartney M, Starostina N. (2007). Tip dilation and AFM capabilities in the characterization of nanoparticles. JOM J Miner Met Mater Soc 59: 12-16.

Zweifel UL, Hagström A. (1995). Total counts of marine bacteria include a large fraction of non-nucleoidcontaining bacteria (Ghosts). Appl Environ Microbiol 61: $2180-2185$.

Supplementary Information accompanies the paper on The ISME Journal website (http://www.nature.com/ismej) 